\title{
A significant relationship between personality traits and adhesive capsulitis
}

\author{
(iD) Rita Chiaramonte ${ }^{1}$ \\ (iD) Marco Bonfiglio ${ }^{2}$ \\ (D) Sergio Chisari ${ }^{3}$
}

1. Department of Physical Medicine and Rehabilitation, University of Catania. 95125 Catania, Italy; 2. General Medicine, ASP Siracusa. 96100 Siracusa, Italy; 3. Pain Medicine Department. University of Catania. 95125 Catania, Italy.

http://dx.doi.org/10.1590/1806-9282.66.2.166

\section{SUMMARY}

OBJECTIVE: We investigated the associations between adhesive capsulitis (AC) and a specific psychological profile.

METHODS: We assessed 72 patients with phase-II AC. In our study, 36 patients were affected by primary disease and 36 by secondary disease. The inclusion criteria were as follows: unilateral AC and pain in the shoulder for at least two months. The exclusion criteria were: psychiatric and neurological manifestations with a previous diagnosis and inability to comprehend the instruments. Outcomes were determined at 52 weeks. Shoulder pain severity was assessed with the Visual Analog Scale. We also measured the range of motion with a universal goniometer and the strength with the Medical Research Council. We assessed the personality traits of our patients with the Cloninger's Temperament and Character Inventory and the Multidimensional Perfectionism Scale.

RESULTS: Patients with primary AC needed more time to improve the symptomatology compared to the group with the secondary disease $(p<0.01)$. Patients with primary AC complained of severe and lasting pain more frequently than patients with the secondary disease ( $p$ 0.01). In patients with primary disease, the prevalence of perfectionism, low levels of novelty seeking, and high levels of harm avoidance were 88.2 and $86.2 \%$, and 80.4, respectively, and below 20 percent in patients with secondary AC disease.

CONCLUSION: We found a significant correlation between primary AC and particular personality traits, indicating an interaction between psychological and somatic factors.

KEYWORDS: Range of motion, articular. Shoulder pain. Bursitis. Personality. Somatoform disorders.

\section{INTRODUCTION}

Adhesive capsulitis: a disease not to be underestimated

Adhesive capsulitis (AC) is characterized by adhesion and fibrosis in the shoulder capsule, decreased volume of the glenoid capsule and progressive loss of range of motion (ROM), shoulder pain and stiffness, causing severe disability.
The prevalence of shoulder pain has been reported to be between $4 \%$ and $26 \%$. Primary AC reportedly affects $2 \%$ to $5.3 \%$ of the general population. The prevalence of secondary AC, related to diabetes mellitus and thyroid disease, is reported to be between $4.3 \%$ and $38 \%$. Prolonged immobilization, myocardial infarction, trauma, and autoimmune disease are other risk factors associated with secondary AC. AC is more

DATE OF SUBMISSION: 01-Jul-2019

DATE OF ACCEPTANCE: 29-Jul-2019

CORRESPONDING AUTHOR: Rita Chiaramonte

Department of Physical Medicine and Rehabilitation. University of Catania, via Santa Sofia, 78 - 95100, Catania - Italy

Fax: +390957315384 - Tel.: +393895114718

E-mail: ritachiaramd@gmail.com 
prevalent in individuals who are 40 to 65 years of age, female, with a previous episode of AC in the contralateral $\mathrm{arm}^{2}$. It is still unclear whether there is any association of psychological traits comorbid with AC.

The condition usually lasts $2-3$ years, but in about $40 \%$ of patients, it is not self-limiting; stiffness and disability persist beyond three years ${ }^{3}$. It has three phases: the painful stage that lasts one to two months, the frozen stage with loss of motion and decreased capsular volume lasting several months to a year or longer, and the thawing stage characterized by gradual improvement of range of motion over several months to years. ROM deficits may continue for years.

In most cases, conservative treatment improves symptoms and restores shoulder motion. In refractory cases, an arthroscopic capsular release is indicated. However, conservative and surgical management of $\mathrm{AC}$ is often prolonged and painful ${ }^{4}$.

The diagnosis of AC is determined from the history and physical examination. Patients typically present with a gradual and progressive onset of pain, likely sleep-disturbing night pain, and pain at end ranges of movements. Patients also present with painful and restricted active and passive ROM of at least $60 \%$ in total active ROM in the affected shoulder compared with the unaffected contralateral shoulder; with the scapula stabilized, in both elevation and rotation that occurs for at least one month and has either reached a plateau or worsened ${ }^{2}$.

\section{Relationship between personality traits and} AC

Behavioral observations and key features of the physical examination have greatly helped clinicians to identify both the presence and severity of diseases, as well as of $\mathrm{AC}^{5}$.

We assessed the relationship between personality traits, using the Cloninger's Multidimensional Perfectionism Scale (MPS) ${ }^{6}$ and Temperament and Character Inventory (TCI) ${ }^{7}$, and the clinical characteristics of patients with AC (pain, ROM, time to recover, ROM, straight).

\section{Purpose}

The purpose of this study was to determine whether psychological factors could influence the results of the rehabilitative treatment of AC. We hypothesized that psychosomatic factors would be correlated with greater pain and delay in the recovery of ROM. We verified the effectiveness of a rehabilitation program for the management of AC associated with psychosomatic disorders. In addition, we performed a review of the literature on psychosocial factors related to AC.

\section{METHODS}

All procedures performed in our study involving human participants were in accordance with the ethical standards of the institution and national research committee and with the 1964 Helsinki declaration and its later amendments or comparable ethical standards. Informed consent was obtained from all individual participants included in the study.

\section{Study Design and Data Collection}

We conducted a retrospective study at the Pain Medicine Department of our University from October 2017 to May 2018. A total of 80 potentially eligible outpatients were screened, 72 of whom met the inclusion criteria. The inclusion criteria were as follows: clinical diagnose of unilateral idiopathic or secondary AC (restricted active ROM of at least $60 \%$ in total active ROM in the affected shoulder compared with the unaffected contralateral shoulder), patients with phase-II $\mathrm{AC}$, pain in the shoulder for at least two months (mean VAS score of 9), who completed one year of physical therapy. Endocrinology disease, immobilization after surgical rotator cuff repair, or trauma were considered for the secondary AC group. Exclusion criteria were as follows: psychiatric and neurological manifestations with a previous diagnosis, history of inflammatory rheumatic disease, musculoskeletal deformities, peripheral neuropathy, major medical conditions such as unstable hypertension, severe cardiac and respiratory problems. Patients with an inability to comprehend the instruments were also excluded (Fig. 1).

\section{Procedures}

We assessed patients with phase-II AC; 36 patients (30 men and 6 women) were affected by primary AC and 36 by secondary AC ( 28 men and 8 women). The mean age was 55 years (range, 32-71 years). The mean duration of symptoms was 8.9 months (ranged from 8 weeks to 24 months). A questionnaire was used to collect sociodemographic data, including age, marital status, educational level, employment status, and total family income. The groups were homogeneous for relevant sociodemographic and general clinical features. Recorded clinical characteristics included the 


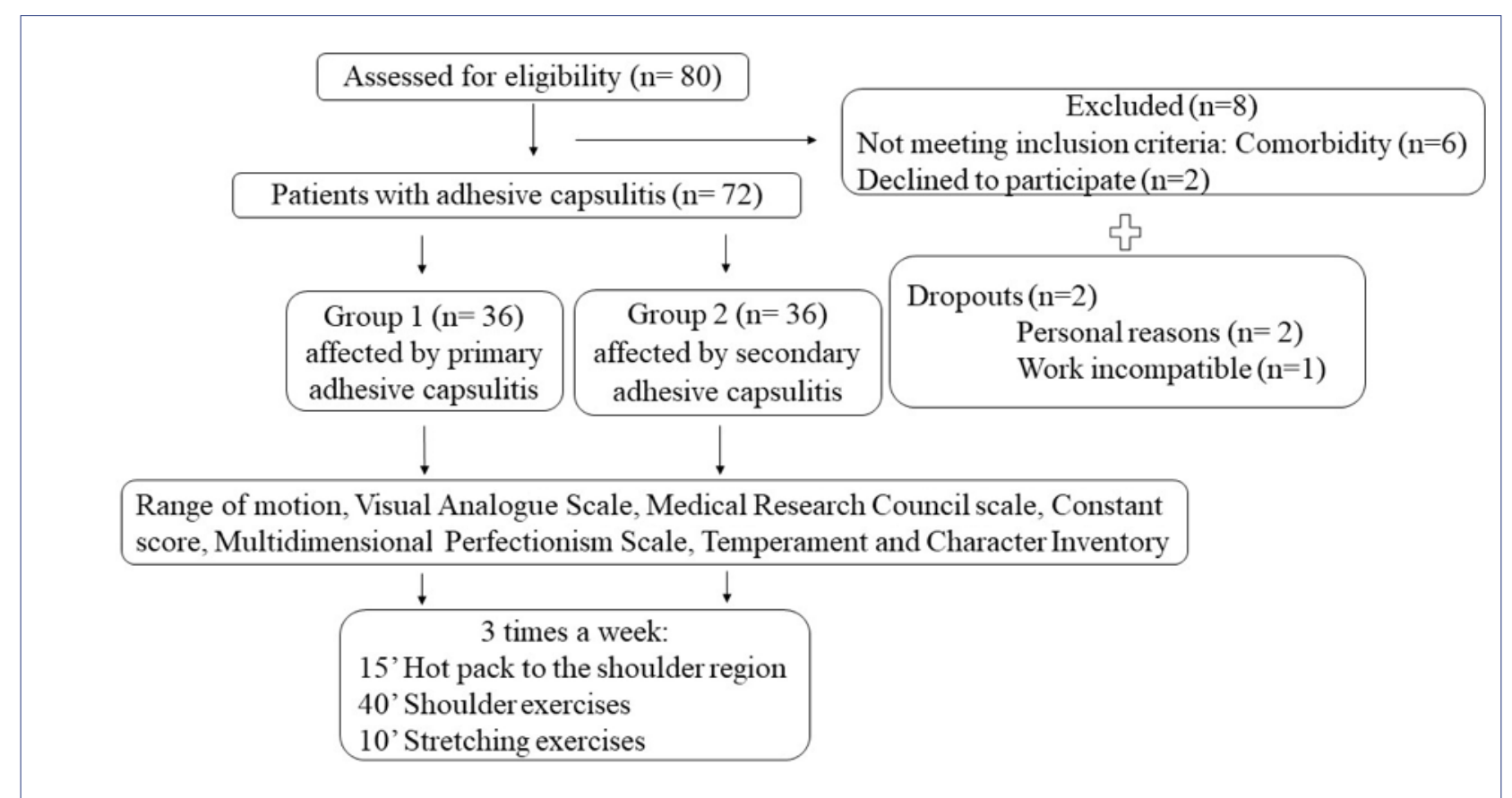

length of history of AC symptomatology and current pharmacological treatment (steroid and nonsteroidal anti-inflammatory drugs) (Table 1).

\section{Outcome measures}

The patients of both groups were evaluated before the training program and 12 months after the suspension of the treatment.

Shoulder pain severity and subsequent sleep disturbances were assessed with a numeric range from 0 to 10 centimeters on the Visual Analog Scale (VAS). We also measured the range of motion (ROM: flexion, abduction, and external rotation) and the strength with the Medical Research Council scale (MRC) and Constant score (CMS) ${ }^{8}$. MRC grades muscle power on a scale of 0 to 5. CMS is a 100-points scale composed of a number of parameters that define the level of pain, strength, ROM, and the ability to carry out normal daily activities of the patient. The same Orthopedic and Physiatrist MD evaluated all the patients. Active shoulder flexion and abduction ROM were assessed with a universal goniometer.

During the first evaluation, patients were approached and interviewed in person during a psychiatric consultation. The personality traits of our patients were determined by the validated Italian version of the $\mathrm{TCI}^{7}$ and the validated Italian MPS $^{9}$. The TCI assessed personality by describing aspects of temperament and character. Several studies considered temperament as the more heritable personality component. It was stable throughout life and responsible for adaptive emotional responses and behavioral reactions to life experiences. The TCI was used to assess the tendency to depression and anxiety through four dimensions: harm avoidance (HA), novelty seeking (NS), reward dependence (RD), and persistence $(\mathrm{P})$. In contrast, character was considered the more learned personality component. It matured throughout adulthood. It was assessed through three dimensions: self-directedness (SD), cooperativeness (C), and self-transcendence (ST) ${ }^{6}$. The MPS was used to measure perfectionism ${ }^{7}$. In the MPS, there was not a clinical cut-off score, but higher scores correlated with perfectionistic attitudes, especially after a significant stressful event ${ }^{7}$.

TABLE 1. PATIENTS' DEMOGRAPHIC DETAILS AT BASELINE

\begin{tabular}{l|l|l} 
Baseline parameters & $\begin{array}{l}\text { Group 1 }(\mathrm{n}= \\
\text { 36) Primary } \\
\text { AC }\end{array}$ & $\begin{array}{l}\text { Group 2 }(\mathrm{n}= \\
\text { 36) Second- } \\
\text { ary AC }\end{array}$ \\
\hline Age, years, yr, mean \pm SD & $51.5 \pm 21.7$ & $50.1 \pm 21.0$ \\
\hline Males & 30 & 28 \\
\hline Females & 6 & 8 \\
\hline $\begin{array}{l}\text { Mean duration of symptoms } \\
\text { (months) }\end{array}$ & $8.9 \pm 13.0$ & $8.1 \pm 12.4$ \\
\hline Years of education yr, mean \pm SD & $13.1 \pm 5.01$ & $16.6 \pm 1.9$ \\
\hline $\begin{array}{l}\text { Occupation: Leave of absence, } \%, \\
\text { mean } \pm \text { SD }\end{array}$ & $30.0 \pm 0.8$ & $32.2 \pm 0.4$ \\
\hline Occupation: Working from home & $35.8 \pm 0.8$ & $36.0 \pm 0.4$ \\
\hline Occupation: Others & $31.3 \pm 1.2$ & $31.8 \pm 0.9$ \\
\hline
\end{tabular}

Abbreviations: AC, adhesive capsulitis; SD, standard deviation; yr, years. 


\section{The Rehabilitation Program}

The same therapists applied the rehabilitation program every time (3 times/week for one year), with progressive exercises. Patients underwent a rehabilitation program, performing standardized shoulder exercises 40 minutes daily, three times a week, for three months. Before physiotherapy exercises, the patients applied a hot pack to the shoulder region for 15 minutes. Then, stretching exercises included wand and Codman pendulum exercises (4 repetitions for each exercise), scapular elevation, adduction, and scapular stabilization exercises (20 repetitions for each exercise). At the end of every sitting, the patients applied an ice pack to the shoulder for 15 minutes. Over the year, the progression of the rehabilitation program provided warm-water exercise, aerobic training, progressive strength exercises, coordination and stretching exercises (Fig. 2). Each week, during physiotherapy sessions, patients were evaluated by physiotherapists, and by physicians each month. Outcomes were determined at 52 weeks.

\section{Statistical Analysis}

The Statistical Package for Social Sciences (SPSS, Version 18.0 for Windows; SPSS Inc., Chicago, IL) was used for data analysis. Quantitative data were compared using the t-test, and qualitative data were compared using $\chi^{2}$ test; $p<0.05$ was considered with statistical significance.

\section{RESULTS}

At the baseline evaluation, the mean active anterior elevation was $90^{\circ},-10^{\circ}$ of external rotation, and internal rotation level reached ipsilateral gluteus in both groups. After a year, the group with primary AC improved the ROM; the mean active elevation was $150^{\circ}, 30^{\circ}$ of external rotation, and internal rotation at level T12. Thus, the average gains were statistically significant $(p<0.001): 60^{\circ}$ in forward active elevation, $40^{\circ}$ in external rotation, $50^{\circ}$ in internal rotation. Similar improvements in shoulder ROM in the group with secondary AC were obtained after 12 months, without a significant difference between groups 1 and 2 (p>0.05) (Table 2).

The results showed that 12 months after the end of the training, the days required for the recovery of patients with primary AC were about 358 , whereas for secondary AC they were 228 . These values were statistically significant $(\mathrm{p}<0.001)$ in the comparison between the two groups.

The mean results of CMS are described in table 2 . In both groups, there was a significant difference in the partial and total scores of CMS 12 months after the end of the training $(p<0.001)$. There was a significant difference in the partial and total score of CMS in group 1 compared to group 2 ( $<<0.001)$, except in the ROM (p>0.05).

Compared to secondary AC, patients with primary AC were characterized by the tendency to be perfectionist, but also fearful, apprehensive, discouraged,

FIGURE 2. DESCRIPTION OF EXERCISES PERFORMED BY BOTH GROUPS DURING A STANDARD SESSION OF TRAINING

\begin{tabular}{|c|c|c|}
\hline Exercises & Time & Description \\
\hline \multicolumn{3}{|c|}{40 minutes daily, 3 times a week } \\
\hline WARM-UP & & \\
\hline Application of hot pack & 5 , & \\
\hline Shoulder stability and fluidity & $\begin{array}{l}20 \text { repetitions for each } \\
\text { exercise for } 5\end{array}$ & $\begin{array}{ll}\text { - } & \text { Scapular elevation, } \\
\text { - } & \text { Adduction and scapular } \\
\text { - } & \text { Stabilization exercises } \\
\end{array}$ \\
\hline AEROBIC EXERCISES & & \\
\hline $\begin{array}{l}\text { Warm-water exercise and } \\
\text { Coordination training }\end{array}$ & $10^{\prime}$ & $\begin{array}{l}\text { Overall mobility using } \\
\text { water as resistance }\end{array}$ \\
\hline ANAEROBIC EXERCISES & & \\
\hline $\begin{array}{l}\text { Progressive strength exercises } \\
\text { with elastic band }\end{array}$ & $10^{\prime}$ & $\begin{array}{ll}\text { - } & \text { Anterior elevation } \\
\text { - } & \text { External rotation } \\
\text { - } & \text { Internal rotation } \\
\end{array}$ \\
\hline STRETCHING & & \\
\hline Flexibility exercises & $\begin{array}{l}4 \text { repetitions for each } \\
\text { exercise for } 10^{\prime}\end{array}$ & $\begin{array}{ll}- & \text { Wand exercises } \\
\text { - } & \text { Codman pendulum exercises }\end{array}$ \\
\hline
\end{tabular}


TABLE 2. ROM AT BASELINE AND AT THE FOLLOW UP IN BOTH GROUPS, OUTCOMES AFTER TREATMENT. CONSTANT SCORE 12 MONTHS AFTER THE END OF TRAINING - A PREVALENCE OF PSYCHOLOGICAL TRAITS IN PATIENTS WITH PRIMARY ADHESIVE CAPSULITIS

\begin{tabular}{|c|c|c|c|c|c|c|c|c|c|c|}
\hline ROM & $\begin{array}{l}\text { Primary } \\
A C A B\end{array}$ & $\begin{array}{l}\text { Primary } \\
\text { AC FU }\end{array}$ & DS & $\begin{array}{l}\text { Paired } \\
\text { t-test }\end{array}$ & P-value & $\begin{array}{l}\text { Secondary } \\
A C A B\end{array}$ & $\begin{array}{l}\text { Secondary } \\
\text { AC FU }\end{array}$ & DS & $\begin{array}{l}\text { Paired } \\
\text { t-test }\end{array}$ & P-value \\
\hline Anterior elevation & $89.8^{\circ}$ & $149.9^{\circ}$ & 5.3 & 67.4 & $p<0.001$ & $90.1^{\circ}$ & $150.2^{\circ}$ & 6.0 & 50.9 & $p<0.001$ \\
\hline External rotation & $-9.4^{\circ}$ & $30.9^{\circ}$ & 2.5 & 93.6 & $p<0.001$ & $-10.1^{\circ}$ & $31.2^{\circ}$ & 3.1 & 70.9 & $p<0.001$ \\
\hline Internal rotation & $30.6^{\circ}$ & $80.0^{\circ}$ & 4.1 & 48.0 & $p<0.001$ & $31.8^{\circ}$ & $82.0^{\circ}$ & 9.8 & 48.2 & $p<0.001$ \\
\hline $\mathrm{ROM}$ & $\begin{array}{l}\text { Primary } \\
A C A B\end{array}$ & $\begin{array}{l}\text { Secondary } \\
A C A B\end{array}$ & DS & $\begin{array}{l}\text { Unpaired } \\
\text { t-test }\end{array}$ & P-value & $\begin{array}{l}\text { Primary AC } \\
\text { FU }\end{array}$ & $\begin{array}{l}\text { Secondary } \\
\text { AC FU }\end{array}$ & DS & $\begin{array}{l}\text { Unpaired } \\
\text { t-test }\end{array}$ & P-value \\
\hline Anterior elevation & $89.8^{\circ}$ & $90.1^{\circ}$ & 3.6 & 1.3 & $p>0.05$ & $149.9^{\circ}$ & $150.2^{\circ}$ & 2.9 & 2.7 & $p>0.05$ \\
\hline External rotation & $-9.4^{\circ}$ & $-10.1^{\circ}$ & 2.8 & 2.0 & $p>0.05$ & $30.9^{\circ}$ & $31.2^{\circ}$ & 1.8 & 3.0 & $p>0.05$ \\
\hline Internal rotation & $30.6^{\circ}$ & $31.8^{\circ}$ & 3.1 & 1.9 & $p>0.05$ & $80.0^{\circ}$ & $82.0^{\circ}$ & 2.4 & 1.8 & $p>0.05$ \\
\hline
\end{tabular}

\begin{tabular}{|c|c|c|c|c|c|c|c|c|c|c|}
\hline CMS & $\begin{array}{l}\text { Primary } \\
A C A B\end{array}$ & $\begin{array}{l}\text { Secondary } \\
A C A B\end{array}$ & DS & $\begin{array}{l}\text { Unpaired } \\
\text { t-test }\end{array}$ & $\mathrm{P}$-value & $\begin{array}{l}\text { Primary AC } \\
\text { FU }\end{array}$ & $\begin{array}{l}\text { Secondary } \\
\text { ACFU }\end{array}$ & DS & $\begin{array}{l}\text { Unaired } \\
\text { t-test }\end{array}$ & $\mathrm{P}$-value \\
\hline Pain & $11.4 / 15$ & $14.8 / 15$ & 2.5 & 19.1 & $p>0.05$ & $8.1 / 15$ & $13.2 / 15$ & 1.5 & 9.1 & $p<0.001$ \\
\hline ADL & $16.1 / 20$ & $19.3 / 20$ & 3.1 & 22.9 & $p>0.05$ & $12.3 / 20$ & $18.5 / 20$ & 3.4 & 14.8 & $p<0.001$ \\
\hline $\mathrm{ROM}$ & $32.4 / 40$ & $38.1 / 40$ & 4.0 & 28.1 & $p>0.05$ & $27.7 / 40$ & $37.8 / 40$ & 6.4 & 2.4 & $P>0.05$ \\
\hline Strength & $16.8 / 25$ & $21.7 / 25$ & 2.1 & 18.2 & $p>0.05$ & $12.2 / 25$ & $19.3 / 25$ & 4.0 & 15.9 & $p<0.001$ \\
\hline Total & $77.2 / 100$ & $93.1 / 100$ & 8.1 & 32.1 & $p>0.05$ & $59.8 / 100$ & $87.6 / 100$ & 10.2 & 12.4 & $p<0.001$ \\
\hline CMS & $\begin{array}{l}\text { Primary } \\
A C A B\end{array}$ & $\begin{array}{l}\text { Primary AC } \\
\text { FU }\end{array}$ & DS & $\begin{array}{l}\text { Paired } \\
\text { t-test }\end{array}$ & P-value & $\begin{array}{l}\text { Secondary } \\
A C A B\end{array}$ & $\begin{array}{l}\text { Secondary } \\
\text { AC FU }\end{array}$ & DS & $\begin{array}{l}\text { Paired } \\
\text { t-test }\end{array}$ & P-value \\
\hline Pain & $11.4 / 15$ & $8.1 / 15$ & 3.1 & 10.2 & $p<0.001$ & $14.8 / 15$ & $13.2 / 15$ & 1.2 & 11.2 & $p<0.001$ \\
\hline ADL & $16.1 / 20$ & $12.3 / 20$ & 4.0 & 14.1 & $p<0.001$ & $19.3 / 20$ & $18.5 / 20$ & 1.8 & 15.5 & $p<0.001$ \\
\hline $\mathrm{ROM}$ & $32.4 / 40$ & $27.7 / 40$ & 5.1 & 11.4 & $p<0.001$ & $38.1 / 40$ & $37.8 / 40$ & 1.3 & 12.7 & $p<0.001$ \\
\hline Strength & $16.8 / 25$ & $12.2 / 25$ & 3.8 & 15.2 & $p<0.001$ & $21.7 / 25$ & $19.3 / 25$ & 2.1 & 16.1 & $p<0.001$ \\
\hline Total & $77.2 / 100$ & $59.8 / 100$ & 14.0 & 12.5 & $p<0.001$ & $93.1 / 100$ & $87.6 / 100$ & 6.5 & 14.8 & $p<0.001$ \\
\hline
\end{tabular}

\begin{tabular}{|c|c|c|c|c|c|c|c|c|c|c|}
\hline $\begin{array}{l}\text { Psychological } \\
\text { traits }\end{array}$ & $\begin{array}{l}\text { Primary } \\
A C A B\end{array}$ & $\begin{array}{l}\text { Secondary } \\
A C A B\end{array}$ & DS & $\chi^{2}$ test & P-value & $\begin{array}{l}\text { Primary AC } \\
\text { FU }\end{array}$ & $\begin{array}{l}\text { Secondary } \\
\text { AC FU }\end{array}$ & DS & $\chi 2$ test & P-value \\
\hline Perfectionism & $90.2 \%$ & $17.4 \%$ & 22.5 & 91.1 & $p<0.001$ & $88.2 \%$ & $14.4 \%$ & 22.5 & 79.1 & $p<001$ \\
\hline NS & $89.2 \%$ & $19.2 \%$ & 33.1 & 81.9 & $p<0.001$ & $86.2 \%$ & $16.2 \%$ & 23.1 & 82.9 & $p<001$ \\
\hline $\mathrm{HA}$ & $85.4 \%$ & $16.3 \%$ & 24.0 & 82.1 & $p<0.001$ & $80.4 \%$ & $18.3 \%$ & 24.0 & 78.1 & $p<001$ \\
\hline $\begin{array}{l}\text { Psychological } \\
\text { traits }\end{array}$ & $\begin{array}{l}\text { Primary } \\
A C A B\end{array}$ & $\begin{array}{l}\text { Primary AC } \\
\text { FU }\end{array}$ & DS & $\chi 2$ test & P-value & $\begin{array}{l}\text { Secondary } \\
A C A B\end{array}$ & $\begin{array}{l}\text { Secondary } \\
\text { AC FU }\end{array}$ & DS & $\chi 2$ test & P-value \\
\hline Perfectionism & $90.2 \%$ & $88.2 \%$ & 3.7 & 3.8 & $p>0.05$ & $17.4 \%$ & $14.4 \%$ & & 2.5 & $p>0.05$ \\
\hline NS & $89.2 \%$ & $86.2 \%$ & 4.9 & 2.10 & $p>0.05$ & $19.2 \%$ & $16.2 \%$ & & 1.8 & $p>0.05$ \\
\hline $\mathrm{HA}$ & $85.4 \%$ & $80.4 \%$ & 2.9 & 3.5 & $p>0.05$ & $16.3 \%$ & $18.3 \%$ & & 3.0 & $p>0.05$ \\
\hline
\end{tabular}

Abbreviations: AC, adhesive capsulitis; DS, standard deviation; ROM, range of motion; $A B$, at baseline; FU, follow up; CMS, Constant score; $A D L$, Activity daily living; HA, harm avoidance; NS, novelty-seeking

insecure, negativistic (due to their higher levels on HA), slow tempered, slow to engage, and unenthusiastic (due to their lower levels on NS). Between the two groups, after 12 months, in patients with primary AC, the prevalence of perfectionism, decreased NS, and increased HA were $88.2,86.2 \%$, and 80.4 , respectively, and below 20 percent in patients with secondary AC $(p<001)$ (Table 2). No other tendency for depression and anxiety was found. The results confirmed that perfectionism, high levels of HA, and low levels of NS characterized the subgroup of patients with AC primary. The rehabilitation treatment did not modify the psychological traits of the groups ( $p>0.05)$ (Table 2).

There was a significant association between pain intensity and personality traits. At the beginning of the study, the mean pain intensity was similar between the two groups: 4.1 in the primary AC group, 3.9 in the secondary AC group, without a significant difference between them $(\mathrm{P}>0.05)$. After eight months, in the primary AC group, the mean VAS score was 7 , whereas in the secondary AC group, it was 4 , with a significant difference between the two groups $(p<0.001)$. After 12 months, the mean 
VAS score in the primary AC group was 5, and in the secondary AC group, it was 3 . So, there was a statistically significant $(p<0.001)$ improvement in the VAS score in the group with secondary AC compared to the group with primary AC. Results indicated that patients with primary AC complained more of severe and lasting pain than patients with secondary AC, as of their psychological disorders (Fig. 3).

\section{DISCUSSION}

The study evaluated personality traits in patients with primary and secondary AC. We found a significant correlation between primary adhesive capsulitis and particular personality traits, indicating an interaction between psychological and somatic factors. According to the psychological assessment, patients with primary AC tended to be characterized by psycho-somatic disorder more often than patients with secondary AC. The results confirmed that perfectionism, high levels of HA, and low levels of NS, characterized the subgroup of patients with primary AC. In addition, there was a significant association between pain intensity and personality traits.

The relationship between AC and psychological disorders has been meagerly investigated. A few studies have suggested the existence of a "periarthritic personality" in patients with frozen shoulder ${ }^{10,11}$. An interesting piece of research indicates that depression and anxiety may coexist with $\mathrm{AC}^{10}$. Behavioral observations and key features of the physical examination have greatly helped clinicians to identify both the presence and severity of diseases, as well as of AC. Patients who had syndromes with ill-defined pathologic mechanisms, such as irritable bowel syndrome and fibromyalgia, had significantly high rates of anxiety and depressive disorders 5 . So, in addition to severe medical conditions and musculoskeletal shoulder disorder, we suggest screening for the presence of psychosocial issues that affected prognostication and treatment decision-making for rehabilitation. Stressful life events, psychological distress, depressive and anxiety disorders were associated with a range of medical symptoms without identified pathology, with increased health care utilization and increased $\operatorname{costs}^{12}$. Kelley et al. ${ }^{2}$ underlined that a longer recovery, chronic symptoms, and work loss in patients with shoulder pain were correlated with elevated scores on the Tampa Scale of Kinesiophobia and the Fear-Avoidance Beliefs Questionnaire.

According to our results, whatever was the cause of AC, a person's susceptibility to pain could cause a psychological discomfort and encourage the onset of AC. On the basis of AC pathogenesis, multifactorial elements of personality, stress, or depression, amplified by the neurophysiologic effects of disturbed sleep, also due to pain, produced a neurochemical disturbance in CNS function. This perturbation included a reduction or impairment of function involving the pain-modulation pathways ${ }^{13}$. Another piece of research described neuroticism, conscientiousness, openness, and agreeableness

FIGURE 3. FLOW DIAGRAM OF THE RESULTS

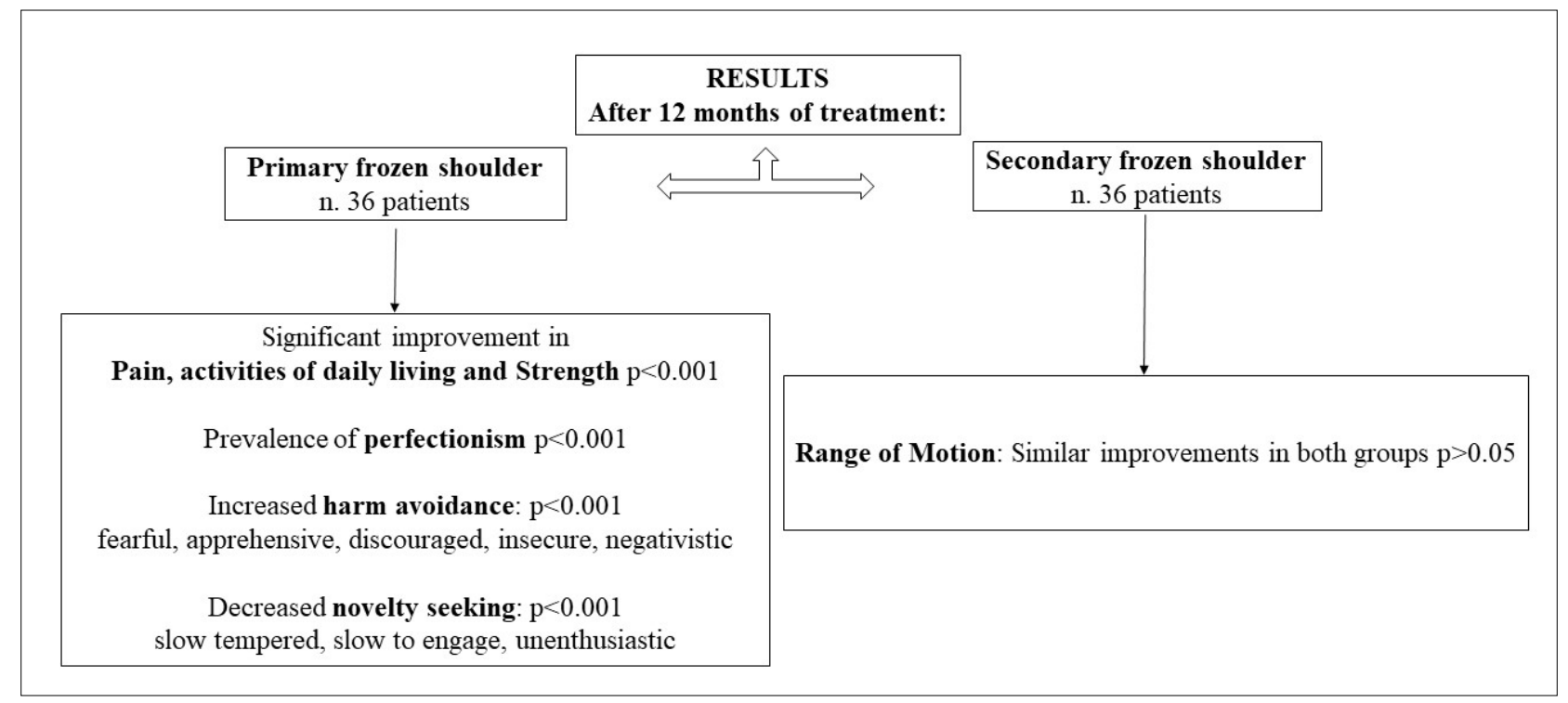


as significant predictors of pain anxiety ${ }^{14}$, and two other studies investigated the relationship between depression and anxiety symptoms in patients with idiopathic $\mathrm{AC}^{15,16}$. According to Ebrahimzadeh et al. ${ }^{15}$ depression is present in $77 \%$ of these patients, anxiety in $27 \%$, and both symptoms in $27 \%$ of their sample. Internal and external rotations were more restricted among patients who had symptoms of depression than elevation and abduction. VAS scores were higher in patients with symptoms of depression ${ }^{15}$. Toprak et al. ${ }^{16}$ did not differentiate between patients with primary and secondary AC; they compared them with a healthy control group and demonstrated a higher prevalence of pain, anxiety, and sleep disturbance in patients with AC, rather than depression symptoms $^{16}$. Both studies ${ }^{15,16}$ confirmed that a psychiatric evaluation could be beneficial in AC patients to formulate the treatment.

Our observations about the peculiar personality traits of patients with AC corroborated findings of previous studies, identifying cognitive-behavioral tendencies. So, the physiatrist could employ specific educational strategies to optimize patient outcomes and potentially provide indications for referring the patient for consultation with a mental health practitioner $^{2,17-19}$.

\section{CONCLUSIONS}

AC is a debilitating condition. Psychological factors can have an effect on pain and shoulder dysfunction. The substantial functional impairment, distress, and costs associated with medical symptoms suggest a better understanding of the biopsychosocial cause of AC.

Patients with primary AC were characterized by the tendency to be perfectionist, but also fearful, apprehensive, discouraged, insecure, negativistic, slow tempered, slow to engage, unenthusiastic. Compared to secondary AC, they complained more about severe and lasting pain than patients with secondary AC.

This analysis should help to provide a specific diagnosis and an eventual additional therapeutic approach to patients with primary AC, evaluating psychological factors. We suggest that personality traits, such as high levels of HA and low levels of NS and perfectionism, may have different responses to treatment. These findings can help to identify patients who potentially require a longer treatment course or those whose outcomes are less satisfactory. According to these findings, personality assessment could be useful in the diagnostic process and in the therapeutic interventions.

\section{RESUMO}

OBJETIVO: Investigar as associações entre a capsulite adesiva (CA) e um perfil psicológico específico.

METODOLOGIA: Foram avaliados 72 pacientes com CA fase II. Em nosso estudo, 36 pacientes foram afetados pela doença primária e 36 pela secundária. Os critérios de inclusão foram os seguintes: CA unilateral e dor no ombro durante por pelo menos dois meses. Os critérios de exclusão foram: manifestações neurológicas e psiquiátricas com um diagnóstico prévio e incapacidade de compreender os instrumentos de medição utilizados. Os resultados foram determinados após 52 semanas. A intensidade da dor no ombro foi avaliada usando a Escala Visual Analógica. Também medimos a amplitude de movimento com um goniômetro universal e a força com a escala do Conselho de Pesquisa Médica. Avaliamos os traços da personalidade dos nossos pacientes através do Inventário de Temperamento e Caráter de Cloninger e da Escala Multidimensional de Perfeccionismo.

RESULTADOS: Pacientes com CA primária precisaram de mais tempo para melhorar a sintomatologia quando comparados ao grupo secundário $(p<0,01)$. Pacientes com CA primária apresentaram mais queixas de dor intensa e duradoura do que pacientes secundários $(p<0,01)$. Em pacientes com a doença primária, a prevalência de perfeccionismo, baixos níveis de procura por novidade, e altos níveis de prevenção de danos foram 88,2, 86,2\% e 80,4, respectivamente, e abaixo de 20\% em pacientes secundários.

CONCLUSÃo: Encontramos uma correlação significativa entre CA primária e traços de personalidade específicos, indicando uma interação entre fatores psicológicos e somáticos.

PALAVRAS CHAVE: Amplitude de movimento articular. Dor de ombro. Bursite. Personalidade. Transtornos somatoformes.

\section{REFERENCES}

1. Murphy RJ, Carr AJ. Shoulder pain. BMJ Clin Evid. 2010;2010. pii:1107.

2. Kelley MJ, Shaffer MA, Kuhn JE, Michener LA, Seitz AL, Uhl TL, et al. Shoulder pain and mobility deficits: adhesive capsulitis. J Orthop Sports Phys Ther. 2013;43(5):A1-31.
3. Balcı NC, Yuruk ZO, Zeybek A, Gulsen M, Tekindal MA. Acute effect of scapular proprioceptive neuromuscular facilitation (PNF) techniques and classic exercises in adhesive capsulitis: a randomized controlled trial. J Phys Ther Sci. 2016;28(4):1219-27. 
4. Arce G. Primary frozen shoulder syndrome: arthroscopic capsular release. Arthrosc Tech. 2015;4(6):e717-20.

5. Katon W, Sullivan M, Walker E. Medical symptoms without identified pathology: relationship to psychiatric disorders, childhood and adult trauma, and personality traits. Ann Intern Med. 2001;134(9 Pt 2):917-25.

6. Cloninger CR, Svrakic DM, Przybeck TR. A psychobiological model of temperament and character. Arch Gen Psychiatry. 1993;50(12):975-90.

7. Fossati A, Cloninger CR, Villa D, Borroni S, Grazioli F, Giarolli L, et al. Reliability and validity of the Italian version of the Temperament and Character Inventory-Revised in an outpatient sample. Compr Psychiatry. 2007;48(4):380-7.

8. Murena L, Vulcano E, D'Angelo F, Monti M, Cherubino P. Italian cross-cultural adaptation and validation of the Oxford Shoulder Score. J Shoulder Elbow Surg. 2010;19(3):335-41.

9. Frost $\mathrm{RO}$, Marten $\mathrm{P}$, Lahart $\mathrm{C}$, Rosenblate $\mathrm{R}$. The dimensions of perfectionism. Cognitive Therapy Res. 1990;14(5):449-68.

10. Ding H, Tang Y, Xue Y, Yang Z, Li Z, He D, et al. A report on the prevalence of depression and anxiety in patients with frozen shoulder and their relations to disease status. Psychol Health Med. 2014;19(6):730-7.

11. Debeer P, Franssens F, Roosen I, Dankaerts W, Claes L. Frozen shoulder and the Big Five personality traits. J Shoulder Elbow Surg. 2014;23(2):221-6.
12. Rouveix M, Bouget M, Pannafieux C, Champely S, Filaire E. Eating attitudes, body esteem, perfectionism and anxiety of judo athletes and nonathletes. Int | Sports Med. 2007;28(4):340-5.

13. Rice JR. "Fibrositis" syndrome. Med Clin North Am. 1986;70(2):455-68.

14. Martínez MP, Sánchez Al, Miró E, Medina A, Lami MJ. The relationship between the fear-avoidance model of pain and personality traits in fibromyalgia patients. J Clin Psychol Med Settings. 2011;18(4):380-91.

15. Ebrahimzadeh $\mathrm{MH}$, Moradi A, Bidgoli HF, Zarei B. The relationship between depression or anxiety symptoms and objective and subjective symptoms of patients with frozen shoulder. Int | Prev Med. 2019;10:38.

16. Toprak M, Erden M. Sleep quality, pain, anxiety, depression and quality of life in patients with frozen shoulder. I Back Musculoskelet Rehabil. 2019;32(2):287-91.

17. Karels $\mathrm{CH}$, Bierma-Zeinstra $S M$, Burdorf $A$, Verhagen $A P$, Nauta AP, Koes BW. Social and psychological factors influenced the course of arm, neck and shoulder complaints. J Clin Epidemiol. 2007;60(8):839-48.

18. Bergbom S, Boersma K, Overmeer T, Linton SJ. Relationship among pain catastrophizing, depressed mood, and outcomes across physical therapy treatments. Phys Ther. 2011;91(5):754-64.

19. Wolf JM, Green A. Influence of comorbidity on self-assessment instrument scores of patients with idiopathic adhesive capsulitis. J Bone Joint Surg Am. 2002;84(7):1167-73 